\title{
Working with Information Systems - the Role of the Professional
}

\author{
Richard SIZER \\ CEng FIEE FBCS CITP \\ Chairman, Ethics Expert Panel, British Computer Society \\ Richardtsz@aol.com
}

Key words: Information Systems, professionalism, personnel, codes of conduct, regulation, powers of sanction.

\section{INTRODUCTION}

The integrity of personnel, their 'professionalism', is a key requirement in working with Information Systems (IS). One way of achieving a measure of professionalism is by means of codes governing behaviour in terms of conduct (how the individual behaves in moral or ethical terms) and practice (how the individual carries out work in technological terms): both should be backed by disciplinary procedures.

\section{PERSONNEL}

Few, if any, systems are immune to misuse by personnel whose professionalism, at all levels, is a significant requirement for achieving the state of 'fitness for the purpose' for which the use of a given IS is intended. Codes of conduct and practice are one way of achieving professionalism but their effectiveness is dependent on powers of sanction (disciplinary 
procedures). However, the term 'professional' is often used ambiguously. Thus, for present purposes, definitions [1] of the terms which are associated with 'professionalism and professional status' are given first to make clear its meaning in the remainder of the chapter.

\section{DEFINITION OF TERMS ASSOCIATED WITH PROFESSIONAL STATUS}

It is meaningful to start with 'amateur' - one who engages in a pursuit, sport, study or science for love, not remuneration. In a sense, the opposite of 'amateur' is 'professional', which has two definitions - (i) one who takes remuneration for participating in an activity or field of endeavour often engaged in by amateurs; (ii) one who conforms to the technical and/or ethical standards of a profession. 'Profession' is: a calling requiring specialised knowledge and often long and intensive academic preparation.

Professionals are, by implication, subject to regulation. 'Regulation' has two definitions - (i) an authoritative rule dealing with details of procedure; (ii) a rule or order having the force of law. Broadly, there are three forms of regulation[2] - (i) state regulation; (ii) regulation of a given group of professionals by a higher, independent body (sometimes referred to as devolved self-regulation); (iii) self-regulation by a body involved in, and comprised of members, of the activity being regulated. Control is effected in the case of State regulation by statute, by disciplinary procedures in the case of chartered bodies and, with self-regulation, by, for example, public reprimand, a monetary fine, withdrawal of registration and the law.

The regulated professions may be characterised by groups - one group provides a service based on confidence or trust such as barristers, solicitors and patent agents. A second group provides a vital service such as medicine, pharmacy, nursing and midwifery whilst a third group is identified with public safety such as airline pilots, captains of ships and mine managers.

It is convenient in this chapter to refer to regulated professionals as 'chartered'; a 'charter' is a grant or guarantee of rights, franchises or privileges from the sovereign power of a state or country. Such chartered professionals (devolved) are regulated by 'sanction' - (i) a principle or influence that impels to moral action or determines moral judgement; (ii) a mechanism of social control for enforcing a society's standards. Moore[3] and Saunders, Carr and Wilson[4] show that the professional, as defined above, is loosely descended from the European craftsmen's Guilds and Inns of medieval times. Interestingly, clerics formed the first identifiable intellectual professional group, membership of which required the achievement and maintenance of personal criteria which excluded virtually 
all other members of contemporary society. There was elitism in its purest form!

In the definition of 'professional' given above, reference is made to 'ethical standards'. We need, now, to define 'ethic': there are three definitions - (i) the discipline dealing with what is good and bad and with moral duty and obligation; (ii) a set of moral principals or values; (iii) the principles of conduct governing an individual or group.

\section{PROFESSIONALISM IN THE CONTEXT OF IS}

It is difficult to fit IS per se into the groups of regulated professionals given above, a point recognised by Parker [5]

Individual practitioners of the three professions of law, religion and medicine can do a great deal of harm, but, in general terms, only to one person at a time. Engineers can harm many people at one crack, but this is less likely because engineers tend to have their work checked and.....work as a team. The possibilities of information processing doing great harm to society are increasing rapidly, however, and it tends to be very difficult to check an individual's work in detail.

Parker wrote the above words before the proliferation of personal computers and mass communication. It is likely, too, that all he had in mind was the lack of good engineering practice of work-checking in the IS fraternity. In today's wide-spread environment of malicious attacks on, and exploitation of, IS, coupled with a general lack of standards, his words are particularly germane.

\section{THE APPROACH OF THE BRITISH COMPUTER SOCIETY (BCS)}

The BCS is the only chartered body in the UK concerned specifically with IS. A brief description of the BCS is given at Appendix 1 .

An apparent conflict in the 1992 version of the BCS Code of Conduct between what is desirable (in ethical terms) and what is enforceable had become a matter for public debate[8]. The Ethics Expert Panel was tasked with examining the apparent conflict and concluded that there was, indeed, a problem presented by the, then, Rule 1:

"Members shall in their professional practice safeguard public health and safety and have regard to the protection of the environment.'

Whilst in a general social context few would argue that the rule represented an altruistic aim, it was recognised that, in reality, where what is 
ethically right or wrong in given circumstances is often highly subjective, the rule was inappropriate in the context of a professional body whose members practised in virtually all sectors of industry, commerce and education: taken literally, the rule's application would require the BCS both to expel many existing members and not to accept new members from a wide variety of industrial sectors. This was, clearly, an untenable position and showed the need for an urgent review of the codes.

The review looked first at codes published by other bodies [9], [10], [11], [12], [13] as well as the 1992 version of the BCS code. It was noted that Bye-law 18 of the BCS Regulations requires that:

Every member .... shall exercise his professional skill and judgement to the best of his ability and discharge his professional responsibilities with integrity. He shall at all times order his conduct to safeguard the public interest and to the best of his ability uphold the reputation and dignity of the profession.

The dichotomy between Bye-law 18 and the 1992 version of the Code of Conduct referred to above was, in essence, an inherent conflict between what is desirable and what is enforceable in the Code in terms of a member's personal responsibility stated in Bye-law 18. To clarify matters in professional terms, the Introduction to the new version of the Code of Conduct states:

The Code governs your personal conduct as an individual member of the BCS and not the nature of business or ethics of the relevant authority. It will, therefore, be a matter of your exercising your personal judgement in meeting the Code's requirements.

Relevant authority is defined earlier in the Introduction as:

The person or organisation which has authority over your activity as an individual. If you are a practising professional, this is normally an employer or client. If you are a student, this is normally an academic institution.

The new code is now in the public domain on www.bcs.org/codes

\section{CONCLUSION}

The BCS Code of Conduct represents one method of achieving a measure of professionalism. However, like any code of conduct, or ethics or practice, its effectiveness is dependent on an associated power of sanction. Such powers cannot exist in isolation because their ultimate enforcement depends broadly on two organisational attributes - (i) the power of sanction must reside in, and be administered by, a body relevant to a given professional field, such that there is a manifest result applying directly to a given individual and (ii) a third party has to 'trigger' the application of the power of sanction by 
laying a complaint against the individual to whom, in given circumstances, the code applies.

\section{REFERENCES}

1. Webster's Seventh New Collegiate Dictionary.

2. Alternatives to State Regulation - Better Regulation Task Force 2000, UK Dept. of Trade and Industry.

3. Moore WE, The Professions: Roles and Rules, Russell Sage Foundation 1970.

4. Saunders A, Carr M. and Wilson P. A., The Professions, London Frank Cass 1964.

5. Should Computer Professionals be Licensed? Communications of the $A C M$, May 1971 Vol. 14 No 5.

6. Combating Computer Pornography - Guidance Notes for BCS Members.

7. Written evidence to a BCS Working Party.

8. How high-principled should BCS members be?, Richard Jennings Computer Bulletin, November 2000.

9. Professional Association Research Network (PARN), Code of Conduct 2000.

10. Software Engineering Code of Ethics and Professional Practice, ACM/IEEE Joint Task Force 1999.

11. IEEE, Code of Ethics 1990.

12. Foundation of Professional Ethics, Richard Jennings, 2000.

13. Guidelines for Institution Codes of Conduct, UK Engineering Council 2000.

\section{APPENDIX: THE BRITISH COMPUTER SOCIETY (BCS)}

The BCS is the Chartered Institution for Information Systems Engineering. It enables individuals, organisations and society to maximise the benefits from Information Systems (IS), by setting and maintaining professional standards for IS professionals and initiating and informing debate on IS issues with Government, Industry, and Academia.

As the BCS is a professional body and a learned society, supporting the IS community in the UK and overseas, it recognises individual and organisational professional integrity and technical competence through the award of its professional qualifications. It also sets standards for education and training through its examination, and by inspection and accreditation of university courses and company training schemes. It defines standards for 
professional conduct through its codes of conduct and good practice and advises the UK Government and its agencies on IS-related matters included in proposed legislation, including sponsoring important legislation itself for example the Computer Misuse Act 1990.

In its pursuit of supporting society at large, the BCS also examines and initiates debate on topical IS issues such as safety critical systems, software certification, intellectual property rights and computer pornography.

The BCS offers a wide range of services for individuals and business, among them numerous membership benefits, a network of branches and specialist groups also open to non-members, and on-line discussion forums. The BCS provides professional qualifications that cover all major areas of the IS discipline, and provides models for a recognised set of training standards and methods for maintaining and awarding best practice in IS staff development. It also provides a wide range of knowledge services through its publishing operation, events, competitions and awards, providing a Professional Advice Service and general IS, security and expert witness consultancy services.

The BCS also manages the highly successful European Computer Driving Licence (ECDL) - the international computer skills qualification. More information is available on http://www.bcs.org or call 01793417424 for more information. 